Journal homepage:http://www.interscience.org.uk

DOI:10.18535/ijahm/v7i4.13

Impact Factor: 4.415

\title{
Management of Sirajanya Dusta Vrana W.S.R to Varicose Ulcer.
}

\author{
Dwivedi Amarprakash ${ }^{1}$, Anaya Ashish Pathrikar', Yadav Birender Nisha ${ }^{3}$ \\ ${ }^{1}$ M.S, PhD,Professor \& Head, Department of Shalya Tantra, D.Y.Patil School of Ayurveda, Navi Mumbai, \\ Maharashtra, India. \\ ${ }^{2}$ M.D, Professor \& Head, Department of Kayachikitsa, AVPM'S Ayurved Mahavidyalaya, Sion, Mumbai, \\ Maharashtra, India. \\ ${ }^{3}$ M.S.(Scholar), Department of Shalya Tantra, D. Y. Patil School Of Ayurved, Navi Mumbai, Maharashtra, \\ India.

\section{Corresponding Author : Dr. Nisha Birender yadav} \\ M.S.(Shalya - Scholar) Dara Elcave, Army Colony, sector-9, E block, flat no 801, Nerul, Navi Mumbai.
}

\begin{abstract}
Varicose Ulcers are wounds which occur due to improper functioning of venous valves, usually of the lower limbs.It is one of the most serious chronic venous insufficiency complications, occurring in $70 \%$ to $90 \%$ of chronic wound cases. If this ulcer is not treated properly, it may get infected leading to cellulitis or gangrene and eventually may need amputation of the limb.

If the conservative management like compression stocking, foot elevation, antibiotics, regular dressing of wound fails, then surgical treatment like skin grafting, sclerotherapy, laser ablation or surgical correction of superficial venous reflux is done. However, recurrence of venous ulcers is common, ranging from 54 to $78 \%$ by the fifth year after healing.

In Ayurveda, varicose ulcers can be correlated with "sira jayna dusta vrana". In Sushrut Samhita, where we get the most scientific description of wounds and its management. So these kind of wounds can be managed with the specific ayurvedic adjuvent therapies.

Considering all these, the present study was taken up with the objective of evaluating efficacy of shanshamni vati(internally) and jatyadi taila(local application)in the management of varicose ulcer. The symptoms like pain, oedema, hyper pigmentation, size of ulcer, granulation tissue were assessed during the treatment. The trial drug proved statistically significant in relieving theabove symptoms. The results revealed that the estimated treatment showed significant improvement $(\mathrm{p}<0.01)$ in all cardinal signs and symptoms. Adjuvant treatment with jatyadi taila(local application) and shanshamni vati(orally) statistically proved to be much potent and effective in management of varicose ulcer, hence study concludes ancient management is safe, easily available devoid of complication and has better acceptability.
\end{abstract}

Key words: shanshamni vati, jatyadi taila, Varicose ulcer management, vrana upakarma, sira janya dusta vrana.

\section{INTRODUCTION:}

Varicose vein are the part of penalty we pay for the adoption of erect posture. The overall incident rate is $0.76 \%$ in men and $1.42 \%$ in women. ${ }^{\{1\}}$ They are also known as stasis ulcer or venous ulcers and are most commonly seen in the female population.Most comman aetiological factors include increased intra venous pressure secondary to DVT, chronic constipation, long standing occupation. Chronic long standing cases of 


\section{Dwivedi A. ${ }^{1}$, International Journal of Ayurvedic \& Herbal Medicine 7(4) July.-Aug.2017 (2724-2732)}

varicose veins renders valves incompetent resulting in venous hypertension allowing blood proteins fibrinogen leakage causing varicose ulcer. Deficiency in fibrinolysis causes fibrin to build up around vessels preventing oxygen and nutrients from reaching cells, these fibrin plugs causes ischemia resulting in delayed healing of wounds. ${ }^{[2]}$

Venous hypertension damages capillaries of skin and subcutaneous tissues make them 'glomerulus like'(convoluted) resulting in fibroid process called lipodermatosclerosis from capillaries proliferation and inflammation which if uncontrolled progresses into venous ulceration. ${ }^{[3]}$

Conservatively disease can be managed with compression stockings, foot elevation, antibiotics, and daily dressing of ulcer. Surgical management consist of ultrasound guided foam sclerotherapy, ELVA(Endo Venous Laser Ablation), RFA(Radio Frequency Ablation), Saphenofemoral ligation and Long saphenous vein stripping, skin grafting etc. ${ }^{[4]}$

In Ayurveda, thecomprehensive management of all vranas(wounds) is exclusively described byAcharya Sushruta under shashthi upakarma (sixty procedures). ${ }^{[5]} \mathrm{He}$ has described wound from its different aspects right from the definition, causes, types and their management in detail. While describing the types of vranas, he mentioned the term Dushtavrana which is having clinical features which resembles to the non-healing type of wound according to present medical science. Acharya Sushruta has also explained about vranas (wounds) which is located in lower exrtemities eliminate (pus etc) from below in upper direction (anti gravity drainage) are difficult to cure. There are lot of drugs in different formulations, described for vrana ropan (wound healing) according to its site, types, chronicity but the management of vranas,particularly dustavranas (non healing ulcers) is still a challenge for surgeons.

Jatyadi taila have vrana ropaka (wound healing) and vrana shodhana (wound cleansing) properties which promote wound healing.Sira and snayu are bi product (upadhatu) of rakta(blood) and 'Shanshamni Vati' (guduchi- tinospora cordifolia $)^{[6,7]}$ have raktaprasadniya and shodhak(blood purification), rakta vardhak(improves haematopoiesis) and shothhar(anti inflammatory) characters, guduchi works as immune modulater. Hence it facilitates formation of healthy newer tissues which promote the wound healing. It also strengthens the blood vessels, thus venous valvular dysfunction. .

AIM OF STUDY: To clinically evaluate the efficacy of Sanshamni Vati (internally) and Jatyadi Taila (local application) in the management of varicose ulcer.

\section{OBJECTIVES OF STUDY:}

To evaluate the role of sanshamni vati in management of varicose ulcer.

To evaluate the role of jatyaditaila local application in the management of varicose ulcer.

To evaluate the role of shanshamni vati and jatyadi tailaadjuvantly in management on the parameters of varicose ulcer, i.e. pain, size of ulcer, hyper pigmentation, granulation tissue, oedema.

TYPE OF STUDY:Open Non Comparative Clinical Study.

\section{MATERIALS \& METHODS:}

SOURCE OF DATA: A open clinical study had taken up on the management of varicose ulcer. The sample size was 50 in total. The Patients were collected from inpatient \& outpatient department of Shalyatantra of D.Y Patil Ayurvedic hospital by simple random sampling procedure, fulfilling the selection criteria.

\section{DRUG AND DOSAGE:}

Local application of jatyadi taila once daily. shanshamni vati 250mg 2BD orally.

Duration - 8 weeks 
Dwivedi A. ${ }^{1}$, International Journal of Ayurvedic \& Herbal Medicine 7(4) July.-Aug.2017 (2724-2732)

Clinical features were recorded before the treatment that is on zero day. Changes with the treatment were observed from $1^{\text {st }}$ week till $8^{\text {th }}$ week, as per the Case Record Formof the case sheet, prepared for the study. Follow up: Patients were advised to come to the hospital for daily regular dressing upto 6 weeks and futher follow up after 2 weeks. Clinical observations were recorded systematically and thoroughly.

Advice:Above knee stockings, protein rich diet, two pillows leg elevation, avoid dressing soakage, avoid bare foot walking.

All the raw materialswere collected from the local market. Its identification \& authentication was done from Mithibai college botany department. The drugs were prepared according to textual reference in Rasa Shastra Bhaishajya Kalpana Department of D.Y. Patil school of Ayurveda. Standardization was done from Anchrom Lab.Mulund (east), Mumbai.

Ethical Clearance for the study was taken from Institutional Ethical Committee DYP AYU. PG/2014-15/209-2015.

\section{Methodology:}

\section{Method of preparation:}

Jatyadi taila:

Jatyadi taila was prepared by snehpak vidhi(medicated oil preparation methodology)according to sushrut samhita. $^{[8]}$

1part- kalka dravya; 4parts-sneha dravya (tila taila); 16parts - drava dravya (water).

1part each ofManjistha (Rubia cordifolia), Haridra(Curcuma longa),Jati Patra(Myristica fragrans), Nimba patra(Azadirachta indica), Patola patra (Trichosanthesdiocia roxb), Haritaki ( Terminalia chebula), Karanja(Pongamia pinnata), Yasti(Glycyrrhiza glabra), Padamka(Prunus cyrasoidus), Katuka (Picrorrhia kurrora), Kutaja (Holarrhena antidysentrica), Lodhra (symplocos racemosa), Kamala(Nelumbo nucifer), Daru haridra(Berberis aristata), Sariva(Hemidesmus indicus), Tuttha(CuSO4), beewax were taken. Thickly pulverized all these materials and triturated them on a stone slab along with water to obtain kalka (paste) out of it. Combine with tila taila (4parts) and water (16parts). Cooked the mix methodologically to obtain the medicatedjatyadi taila. ${ }^{[9]}$

\section{Shanshamni vati:}

Raw material (fresh thick bark) of Guduchi drug were cut in small pieces. Crushed the guduchi pieces then boiled it with 4 times water till left $14^{\text {th }}$ of it. Then this guduchi kwatha was boiled over mandagni (low heat) till it reached the thick consistency. Then contents were collected into the tray. The paste obtained was converted into varti. These varti's were subjected into tablet cutting machine. Each tablet is of $250 \mathrm{mg}$. Finally dried in dryer to reduce the moisture contents of it. ${ }^{[10]}$

\section{SELECTION CRITERIA:}

\section{INCLUSIVE CRITERIA:}

Patients diagnosed with varicose ulcer.

Patients irrespective of sex, religion, occupation \& economic status.

Patients in between the age group of 18 to 60 years.

Patients not enrolled in any other clinical trials.

\section{EXCLUSIVE CRITERIA:}

Patients having embolism, bleeding disorder, arterial occlusion disease other infective skin disorders etc.

Patients with immune-compromised diseases like HIV, HbsAg, Cancer etc.

Patient with Diabetes and Hypertension.

Patient with DVT and venous pump failure disease. 
Dwivedi A. ${ }^{1}$, International Journal of Ayurvedic \& Herbal Medicine 7(4) July.-Aug.2017 (2724-2732)

Patients with history of previous surgeries for varicose ulcer.

\section{GRADATION OF PARAMETER:}

The improvement in the patient was assessed mainly on the basis of relief in the cardinal signs \& symptoms of the disease. To assess the effect of therapy, all the signs and symptoms were given scoring depending upon their severity as below:

Subjective and Objective Assessment-

Table -1 Showing the gradation of parameters for assessement.

\begin{tabular}{|c|c|c|}
\hline & Parameter & Gradation \\
\hline \multirow[t]{7}{*}{1.} & Pain & Grade \\
\hline & No pain & 0 \\
\hline & Mild pain & 1 \\
\hline & Moderate pain & 2 \\
\hline & Severe pain & 3 \\
\hline & Worst pain & 4 \\
\hline & \multicolumn{2}{|c|}{ VAS Scale used for pain gradation- $0=0,1-3=1,4-6=2,7-9=3,10=4$} \\
\hline 2. & Size of ulcer & Grade \\
\hline & absent & 0 \\
\hline & $25 \%$ & 1 \\
\hline & $50 \%$ & 2 \\
\hline & Base line & 3 \\
\hline \multirow[t]{5}{*}{3.} & Hyper Pigmentation & Grade \\
\hline & None & 0 \\
\hline & Slight & 1 \\
\hline & Medium & 2 \\
\hline & Heavy & 3 \\
\hline \multirow[t]{5}{*}{4.} & Granulation Tissue & Grade \\
\hline & $100 \%$ & 0 \\
\hline & $75 \%$ & 1 \\
\hline & Island & 2 \\
\hline & No granulation & 3 \\
\hline \multirow[t]{5}{*}{5.} & $\begin{array}{c}\text { Oedema (in cm)- at calf, ankle and } \\
\text { foot }\end{array}$ & Grade \\
\hline & Absent & 0 \\
\hline & $25 \%$ & 1 \\
\hline & $50 \%$ & 2 \\
\hline & $100 \%$ & 3 \\
\hline
\end{tabular}

\section{Assessment criteria-Relief-}

Cured $\quad-100 \%$ relief (100\% Improvement)

Markedly Improved - 51-75\% relief (Marked Improvement)

Improved $\quad-26-50 \%$ relief (Moderate Improvement)

No Change - Below 25\% relief (No Improvement) 


\section{LABORATICAL INVESTIGATIONS:}

\section{CBC and ESR}

2. Blood Sugar 1) Fasting 2) Post Prandial

3. BT, CT, PT

4. Venous Doppler study of lower limb.

5. Urine tests - Sugar, Albumin

6. HIV I \& II,HBsAg

\section{OBSERVATIONS\& RESULT:}

The observed data is grouped under two headings- Demographic analysis and clinical efficacy of treatment during study.

\section{Demographic analysis-}

The age wise distributions of 50 patients showed that maximum number of patients i.e. $46 \%$ belonged to age group of $45-54$ years, followed by $34 \%$ patients to $55-64$ years and $16 \%$ patients to $35-44$ years. Lastly $4 \%$ patients belonged to age Group of 25-34 years.

According to Gender - Among 50 patients, 62\% i.e.31were males, $38 \%$ i.e. 19 were females.

According to Occupation - Among 50 patients, $42 \%$ i.e. 21 patients were businessmen, $22 \%$ i.e. 11 patients were housewives, $22 \%$ i.e. 11 patients were retired, $10 \%$ that is 5 patients were servicemen, $4 \%$ i.e. 2 patients were waiters.

While observing the Nature of diet- it was found that mixed diet patients were majority in number $70 \%$ i.e. 35 patients and $30 \%$ i.e. 15 patients were of vegetarian diet.

While observing Religion- out of 50 patients $86 \%$ i.e.43 patients are Hindus and remaining $14 \%$ i.e.7 patients are Muslims.

According to Prakruti- out of 50 patients $32 \%$ i.e. 16 patients were of Pitta-Kapha, $32 \%$ i.e.16 patients were of Vata-Kapha, $26 \%$ i.e.13 patients were of Vata-Pitta and $10 \%$ i.e. 5 patients were of Kapha-Pitta.

While observing Socio-Economic status- out of 50 patients $62 \%$ i.e. 31 patients were of upper and upper middle class, $26 \%$ i.e. 13 patients were of lower middle class and $12 \%$ i.e.6 patients were of lower class.

While observing family history- $70 \%$ i.e. 35 patients have no family history, while $18 \%$ i.e. 9 patients had paternal family history, $12 \%$ i.e. 6 patients had maternal family history.

While observing Duration - out of 50 patients $30 \%$ i.e. 15 patients had history of varicose ulcer $<12$ months, $24 \%$ i.e. 12 patients had history since 12 months, $14 \%$ i.e. 7 patients had history since 24 months, 26\% i.e. 13 patients had history since 36 months, $6 \%$ i.e. 3 patients had history since 48 months.

\section{Assessment of Results-}

This combination of jatyadi taila local application and shanahmni vati orally have provenstatistically significant in the management of varicose ulcer, as the ' $p$ ' value $<0.001$.

For obtaining observations and results on gradation parameter Wilcoxon's signed rank test and Paired Z test were used.

Table - 2: Gradation parameter Analysis of Patients (Before and After Treatment).

\begin{tabular}{|c|c|c|c|c|c|}
\hline \multirow{2}{*}{$\begin{array}{c}\text { Assessment } \\
\text { parameters }\end{array}$} & Gradation & \multicolumn{2}{|c|}{ Before Treatment } & \multicolumn{2}{c|}{ After Treatment } \\
\cline { 3 - 6 } & & $\mathrm{N}$ & $\%$ & $\mathrm{~N}$ & $\%$ \\
\hline \multirow{3}{*}{$\begin{array}{c}\text { Hyper } \\
\text { Pigmentation }\end{array}$} & None & 0 & 0.0 & 20 & 40.0 \\
\cline { 2 - 6 } & Slight & 0 & 0.0 & 27 & 54.0 \\
\cline { 2 - 6 } & Medium & 3 & 6.0 & 3 & 6.0 \\
\cline { 2 - 6 } & Heavy & 47 & 94.0 & 0 & 0.0 \\
\hline
\end{tabular}


Dwivedi A. ${ }^{1}$, International Journal of Ayurvedic \& Herbal Medicine 7(4) July.-Aug.2017 (2724-2732)

\begin{tabular}{|c|c|c|c|c|c|}
\hline Oedema Calf & Absent & 0 & 0.0 & 31 & 62.0 \\
\cline { 2 - 6 } & $25 \%$ & 0 & 0.0 & 19 & 38.0 \\
\cline { 2 - 6 } & $50 \%$ & 3 & 6.0 & 0 & 0.0 \\
\cline { 2 - 6 } & $100 \%$ & 47 & 94.0 & 0 & 0.0 \\
\hline Oedema Ankle & Absent & 0 & 0.0 & 37 & 74.0 \\
\cline { 2 - 6 } & $25 \%$ & 0 & 0.0 & 13 & 26.0 \\
\cline { 2 - 6 } & $50 \%$ & 3 & 6.0 & 0 & 0.0 \\
\cline { 2 - 6 } & $100 \%$ & 47 & 94.0 & 0 & 0.0 \\
\hline Oedema Foot & Absent & 0 & 0.0 & 37 & 74.0 \\
\cline { 2 - 6 } & $25 \%$ & 0 & 0.0 & 11 & 22.0 \\
\cline { 2 - 6 } & $50 \%$ & 2 & 4.0 & 2 & 4.0 \\
\cline { 2 - 6 } Tissue & $100 \%$ & 48 & 96.0 & 0 & 0.0 \\
\cline { 2 - 6 } & $100 \%$ & 0 & 0.0 & 34 & 68.0 \\
\cline { 2 - 6 } & $75 \%$ & 0 & 0.0 & 16 & 32.0 \\
\cline { 2 - 6 } & Island & 13 & 26.0 & 0 & 0.0 \\
\hline \multirow{4}{*}{ Pain } & Nonulation & 37 & 74.0 & 0 & 0.0 \\
\cline { 2 - 6 } & No pain & 0 & 0.0 & 32 & 64.0 \\
\cline { 2 - 6 } & Mild & 12 & 24.0 & 18 & 36.0 \\
\cline { 2 - 6 } & Moderate & 25 & 50.0 & 0 & 0.0 \\
\cline { 2 - 6 } & Severe & 13 & 26.0 & 0 & 0.0 \\
\cline { 2 - 6 } & Worst & 0 & 0.0 & 0 & 0.0 \\
\cline { 2 - 6 } & Absent & 0 & 0.0 & 37 & 74.0 \\
\cline { 2 - 6 } & $25 \%$ & 0 & 0.0 & 13 & 26.0 \\
\hline \multirow{4}{*}{ Size of Ulcer } & $50 \%$ & 48 & 96.0 & 0 & 0.0 \\
\hline
\end{tabular}

.All the parameters like Hyper pigmentation, Oedema calf, Oedema ankle, Oedema foot, Granulation tissue, Pain and size of ulcer are significantly changed after treatment of Patients. All the given parameters are statistically highly significant at $0.01 \%$ level i.e. $\mathrm{P}<0.001$.

Table $-\mathbf{3}$ show the statistical analysis of parameters of patients before and after treatment.

\begin{tabular}{|c|c|c|c|}
\hline $\begin{array}{c}\text { Parameter } \\
\text { (Before Vs After })\end{array}$ & $\begin{array}{c}\text { Wilcoxon Signed } \\
\text { rank Test }\end{array}$ & P-value & $\begin{array}{c}\text { Significant at 5\% } \\
\text { level }\end{array}$ \\
\hline Hyper pigmentation & 6.327 & $<0.001$ & Yes \\
\hline Oedema Calf & 6.358 & $<0.001$ & Yes \\
\hline Oedema Ankle & 6.446 & $<0.001$ & Yes \\
\hline Oedema Foot & 6.486 & $<0.001$ & Yes \\
\hline Granulation Tissue & 6.306 & $<0.001$ & Yes \\
\hline Pain & 6.295 & $<0.001$ & Yes \\
\hline Size of Ulcer & 6.450 & $<0.001$ & Yes \\
\hline
\end{tabular}

\section{Other Findings-}

After assessing haematological investigations before and after treatment $\mathrm{Hb}, \mathrm{RBC}, \mathrm{BT}, \mathrm{CT}$ are not statistically significant at $5 \%$ level i.e. $\mathrm{P}>0.05$ but WBC, ESR are statistically significant at $0.01 \%$ i.e. $\mathrm{P}<0.001$. 
Dwivedi A. ${ }^{1}$, International Journal of Ayurvedic \& Herbal Medicine 7(4) July.-Aug.2017 (2724-2732)

Table $-\mathbf{4}$ showing the statistical analysis of investigations (before and after treatment).

\begin{tabular}{|l|l|l|l|l|l|l|l|}
\hline Ivestigation & Treatment & $\mathbf{N}$ & Mean & Stdev. & $\mathbf{Z}-$ test & $\begin{array}{c}\text { P } \\
\text { value }\end{array}$ & $\begin{array}{c}\text { Significant } \\
\text { at 5\% level }\end{array}$ \\
\hline Hb & Before & 50 & 12.3560 & 1.5508 & -0.802 & 0.427 & No \\
\hline & After & 50 & 12.4180 & 1.5834 & & & \\
\hline RBC & Before & 50 & 4.3200 & 0.4607 & 1.248 & 0.218 & No \\
\hline & After & 50 & 4.2760 & 0.5723 & & & \\
\hline WBC & Before & 50 & 7624.00 & 1623.75 & 3.707 & 0.001 & Yes \\
\hline & After & 50 & 6672.00 & 1162.87 & & & \\
\hline ESR & Before & 50 & 28.1600 & 15.7199 & 5.872 & 0.000 & Yes \\
\hline & After & 50 & 15.5800 & 12.0138 & & & \\
\hline BT & Before & 50 & 1.7656 & 0.3610 & -1.817 & 0.075 & No \\
\hline & After & 50 & 1.8176 & 0.4659 & & & \\
\hline CT & Before & 50 & 1.7656 & 0.3610 & -1.817 & 0.075 & No \\
\hline & After & 50 & 1.8176 & 0.4659 & & & \\
\hline
\end{tabular}

\section{RESULT:}

Over all Effects of Treatment - 10\% i.e. 5 patients are fully cured where as 54\% i.e. 27 patients are relieved and remaining $36 \%$ i.e. 18 patients are markedly improved. But overall patients improvement are significantly visible. None of patient showed no improvement in size of ulcer and none of the patient showed worsened condition by this adjuvant treatment.

Table -5 Showing the overall result of jatyadi taila and shanshamni vati on 50 patients after treatment.

\begin{tabular}{|c|c|c|}
\hline Result & No. of Patients & Percentage \\
\hline Cured & 5 & $10.0 \%$ \\
\hline Relieved & 27 & $54.0 \%$ \\
\hline Markedly Improved & 18 & $36.0 \%$ \\
\hline No Improvement & 0 & $0.0 \%$ \\
\hline Worsened & 0 & $0.0 \%$ \\
\hline Total & 50 & $100.0 \%$ \\
\hline
\end{tabular}

This study was based on clinical features like pain, hyper pigmentation, granulation tissue, size of ulcer,oedema and calf, ankle foot. Demographic analysis on Independent variables like Age, Gender, Economic status, Religion, Occupation, Diet, Prakruti and duration were assessed but not considered in drawing conclusion.

\section{DISCUSSION:}

Varicose ulcer and its complication are a common recurring problem. The management scheme for venous ulcer oedema, hyper pigmentation have been evolving through years, with the primary goal of reducing venous congestion and enhancing tissue perfusion and wound healing.

Typically conservative management with a regime of double elastic stockings, leg elevation at rest and calf muscle exercise, requires good and prolonged patient compliance and has its own problem.

According to Acharya Shushruta symptoms of siragat vata janya dusta vrana can be co-related to varicose ulcer and treatment regime for these kind of vrana has been explained in sixty measures of wound management. 


\section{Dwivedi A. ${ }^{1}$, International Journal of Ayurvedic \& Herbal Medicine 7(4) July.-Aug.2017 (2724-2732)}

The present study was carried out to establish potent ayurvedic adjuvant treatment for healing of varicose ulcer and reducing oedema, hyperpigmentation by getting rid of venous stasis. On the basis of this study we can conclude that ayurveda can give a ray of hope in treatment of varicose ulcer.

\section{PROBABLE MODE OF ACTION-}

Shanshamni vati have guduchi which comes in traditional rejuvenator Ayurvedic plant category. It supports in the functioning of the immune system by maintaining sufficient levels of WBC (white blood cells) such as macrophages. So it enhances immune system by expelling toxins from the body and rejuvenating the body. Hence it works as immune modulator. [11]

'Sira' and 'Snayu' are the bi product (updhatu) of rakta (blood)and ' shanshamni vati' has 'Raktaprasadniya' character. Hence, it facilitates formation of Healthy Newer tissues and also strengthens the blood vessels, thus corrects venous valvular dysfunction As per Ayurvedic texts, guduchi purifies the Raktadhatu due to its Raktaprasadniyacharacter. Further, once Rakta is purified, its bi product (updhatu) i.e. Sira (veins) and its kinematics also gets pacified, thus may corrects venous valvular dysfunction when used internally along with the adjuvant treatment.

Tikta-kasaya rasa; madhura vipaka; uṣnavirya; tridosashmaka; dipaniya, and dahanashamak are its properties. The chloroform and benzene extracts of guduchi were found to possess significant antibacterial activity as compared with the standard. Guduchi leaf extract is useful in infections due to Proteus vulgaris, Staphylococcus aureus, Streptococcus pyrogens, Bacillus subtilis, and Escherichia coli. ${ }^{[12]}$

Guduchi also includes tinosporal, clombin tinosporal, tinosporic acid and palmarin, the drug possesses $1 / 5^{\text {th }}$ of the analgesic sodium salicaylate effect, that is used commonly as an analgesic medicine. [13]

Jatyadi taila is good shodhna(cleansing) and ropana(healing)drug. Most of the indredients used in jatyadi taila are shothahara (anti inflammatory), vedanasthapana ( analgesic) and ropaka(wound healing), which are important requirements of healing of a wound and relieves pain too. The ingredients like nimba patra(Azadirachta indica) and daruharidra (Beriberiaristata DC) are antibacterial and promote wound healing. [14]

\section{CONCLUSION:}

In this present work on varicose ulcer50 patients were selected according to the criteria and jatyadi taila(daily dressing) was done and shanshamni vati(orally) were given for 6weeks.

While observing Result $10 \%$ i.e. 5 patients are fully cured where as $54 \%$ i.e. 27 patients are relieved and remaining $36 \%$ i.e. 18 patients are markedly improved. But overall patients improvement are significantly visible. None of patient showed no improvement in size of ulcer and none of the patient showed worsened condition by this adjuvant treatment.

Jatyadi taila and shanshamni vati statistically also showed significantly decrease in venous congestion and resulting into reducing of edema and hyper pigmentation and increase granulation and result into wound healing.

These drugs do not affect the Hb, RBC, BT, CT but it help in decrease in WBC and ESR count.

The complication with such therapy are wound infection, hypersensitivity and bleeding. None of the complication was observed in this study. In view of no any adverse effects and affordable economically by all, it can be recommended in combination for adjuvant treatment of varicose ulcer.

\section{FUTURE SCOPE AND LIMITATIONS:}

Multi centric trial can be carried out with larger sample size.

In future it can be used as an alternative option to avoid modern treatment and surgery.

Histopathology study to prove the mechanism of healing of varicose ulcer with jatyadi taila can be done. 


\section{REFERANCES:}

1. Margolis, Bilker W, Santanna J, Baumgarten M. Venous leg ulcer: Incidence and prevalence in the elderly. J Am Acad Dermatol. 2002;46:381-6. [PubMed] date 12-07-2017.

2. Concise Text book Of Surgery by Somen Das, $8^{\text {th }}$ edition,published by S. Das publication 2014, old mayor's court Calcutta, chapter no-16, diseases of vein, page no269.

3. Concise Text book Of Surgery by Somen Das, $8^{\text {th }}$ edition,published by S. Das publication 2014, old mayor's court Calcutta, chapter no-16, diseases of vein, page no268-269.

4. Bailey \& love's short practice of surgery by Norman S. Williams CRC press, Taylor \& Francis Group 2013, $26^{\text {th }}$ edition chapter- 57 page 908-911.

5. Sushrut Samhita Chikitsastan- Dr.Anantramram Sharma Vol- 2 chikitsathan edition 2001, chapter 1, dwivariyachikitsam, shlok no-8 page no146.

6. Dravyaguna Vijnyan [study of the essential medicinal plants in ayurveda] vol-2 by Dr.J.L.N.Sastry, Chaukhambha orientalia publishers, 2010 edition, chapter 3, Guduchi, page no33,34,35.

7. Bhavaprakash Nighantu( Indian material medica) by Bhavamishra, commentry by prof. Krishanchand Chunekar, Chaukhambha bharti academy publishers, edition-2010, chapter 3, shloka no 1-10, page no 257.

8. Sushrut Samhita Chikitsastan- Dr.Anantramram Sharma Vol 2- Chikitsastan, edition-2001, chp 31 Snehopayogik chikitsa adhyay. Shlok no 6- Page no 407.

9. Bhaisajya Ratnavali of Govinda Dasji Bhisagratna edited by Bhisagratna shri brahmashankar mishra, vol-2, Chaukhambha Sanskrit bhawan, edition-2006, shloka no 64,65,66,67. Page no 761.

10. Ayurved Shar- Sangraha, publisher Shri Baidnath Ayurved Bhawan limited. Edition-2013, page no 439.

11. https:/www.google.co.in/amp/s/mavcure.com/guduchi-health-benefits/amp/ 12-07-2017.

12. Nagvalli D, Shri Vijaya Kirubha T, Hemalatha S. Karunambigai inospora Cordifolia (GuduchiAMRUTA) possesses anti-inflammatory, analgesic, antipyretic and immuno suppressive. Medicinal And Aromatic Plant Abstract. 2006;103:350.

13. https://www.google.co.in/amp/s/mavcure.com/gud uchi-health-benefits/amp/ 12-07-2017.

14. Baswa M. Rath CC, Dash SK, Mishra RK, Antibacterial activity of karanj (pongamia pinnata) and neem (Azadirachta indica) seed oil: a preliminary report. Microbios 2001;105(412): 183-89. 